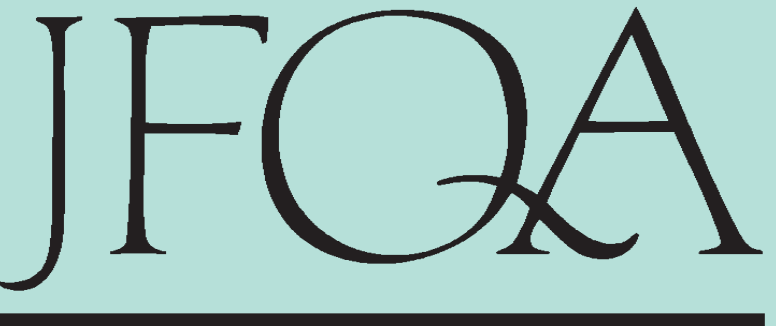

VOL. 51 , NO. 6 DECEMBER 2016

MANAGING EDITORS

Hendrik Bessembinder Jennifer Conrad Jarrad Harford

Paul Malatesta

ADVISORY EDITORS

Stephen Brown

Mark Grinblatt

ASSOCIATE EDITORS

Warren Bailey

Gurdip Bakshi

Turan Bali

Murillo Campello

Mikhail Chernov

Jeffrey Coles

Ran Duchin

Alex Edmans

Wayne Ferson

Jonathan Karpoff

Francis Longstaff

Ronald Masulis

John McConnell

Robert McDonald

Darius Palia

Neil Pearson

George Pennacchi

Jeffrey Pontiff

Jay Ritter

Bryan Routledge

Sergei Sarkissian

Paul Schultz

Chester Spatt

Kumar Venkataraman

Ralph Walkling

Yuhai Xuan

David Yermack

Lu Zhang

Guofu Zhou
Creative Destruction and Asset Prices Joachim Grammig and Stephan Jank

Horizon Pricing

Avraham Kamara, Robert A. Korajczyk, Xiaoxia Lou, and Ronnie Sadka

Liquidity Risk and the Credit Crunch of 2007-2008:

Evidence from Micro-Level Data on Mortgage

Loan Applications

Adonis Antoniades

Cash Holdings, Competition, and Innovation

Evgeny Lyandres and Berardino Palazzo

How Do Frictions Affect Corporate Investment?

A Structural Approach

M. Cecilia Bustamante

Time-Varying Liquidity and Momentum Profits

Doron Avramov, Si Cheng, and Allaudeen Hameed

\section{Urban Agglomeration and CEO Compensation}

Bill B. Francis, Iftekhar Hasan, Kose John,

and Maya Waisman

Spreading the Misery? Sources of Bankruptcy Spillover in the Supply Chain

Madhuparna Kolay, Michael Lemmon, and Elizabeth Tashjian

Sentiment and the Effectiveness of Technical Analysis:

Evidence from the Hedge Fund Industry

David M. Smith, Na Wang, Ying Wang,

and Edward J.Zychowicz

Continuing Overreaction and Stock Return Predictability

Suk Joon Byun, Sonya S. Lim, and Sang Hyun Yun 
JOURNAL OF FINANCIAL AND QUANTITATIVE ANALYSIS

A PUBLICATION OF THE UNIVERSITY OF WASHINGTON MICHAEL G. FOSTER SCHOOL OF BUSINESS IN COOPERATION WITH THE ARIZONA STATE UNIVERSITY

W. P. CAREY SCHOOL OF BUSINESS AND UNIVERSITY OF NORTH CAROLINA KENAN-FLAGLER BUSINESS SCHOOL

VOL. 51, NO. 6, DECEMBER 2016

Creative Destruction and Asset Prices 1739 Joachim Grammig and Stephan Jank

Horizon Pricing 1795

Avraham Kamara, Robert A. Korajczyk, Xiaoxia Lou, and Ronnie Sadka

Liquidity Risk and the Credit Crunch of 2007-2008:

Evidence from Micro-Level Data on Mortgage Loan Applications

Adonis Antoniades

Cash Holdings, Competition, and Innovation

Evgeny Lyandres and Berardino Palazzo

How Do Frictions Affect Corporate Investment?

A Structural Approach

M. Cecilia Bustamante

Time-Varying Liquidity and Momentum Profits 1897

Doron Avramov, Si Cheng, and Allaudeen Hameed

Urban Agglomeration and CEO Compensation 1925

Bill B. Francis, Iftekhar Hasan, Kose John, and Maya Waisman

Spreading the Misery? Sources of Bankruptcy Spillover

in the Supply Chain

Madhuparna Kolay, Michael Lemmon, and Elizabeth Tashjian

Sentiment and the Effectiveness of Technical Analysis:

Evidence from the Hedge Fund Industry

David M. Smith, Na Wang, Ying Wang,

and Edward J. Zychowicz

Continuing Overreaction and Stock Return Predictability 2015

Suk Joon Byun, Sonya S. Lim, and Sang Hyun Yun 


\section{ADVISORY EDITORS Stephen Brown \\ New York University}

Mark Grinblatt

University of California at Los Angeles
ASSOCIATE EDITORS

Warren Bailey
Cornell University
Gurdip Bakshi
University of Maryland
Turan Bali
Georgetown University
Murillo Campello
Cornell University
Mikhail Chernov
University of California at
Los Angeles
Jeffrey Coles
University of Utah
Ran Duchin
University of Washington
Alex Edmans
London Business School
Wayne Ferson
University of Southern
California
Jonathan Karpoff
University of Washington
Francis Longstaff
University of California at
Los Angeles

Ronald Masulis
University of New South
Wales
John McConnell
Purdue University
Robert McDonald
Northwestern University
Darius Palia
Rutgers University

Neil Pearson

University of Illinois at UrbanaChampaign

George Pennacchi

University of Illinois at UrbanaChampaign

\section{Jeffrey Pontiff \\ Boston College}

Jay Ritter

University of Florida

Bryan Routledge Carnegie Mellon University

Sergei Sarkissian

McGill University

Paul Schultz

University of Notre Dame

\author{
Chester Spatt \\ Carnegie-Mellon University
}

Kumar Venkataraman

Southern Methodist University

Ralph Walkling
Drexel University

Yuhai Xuan

University of Illinois at Urbana-Champaign

\section{David Yermack}

New York University

\section{Lu Zhang \\ Ohio State University}

Guofu Zhou

Washington University in St. Louis

\section{BUSINESS AND}

PRODUCTION MANAGER

Susan Huot

University of Washington

PRODUCTION EDITOR

Wendy Katz

University of Washington

The Journal of Financial and Quantitative Analysis (ISSN 0022-1090), Michael G. Foster School of Business, University of Washington, 370 Mackenzie Hall, UW Box 353200, Seattle, WA 98195-3200, is published bimonthly in February, April, June, August, October, and December by Cambridge University Press, One Liberty Plaza, 20th Floor, New York, NY 10006/Cambridge University Press, University Printing House, Shaftesbury Road, Cambridge CB2 8BS, UK for the University of Washington Michael G. Foster School of Business in cooperation with the W. P. Carey School of Business at Arizona State University and the Kenan-Flagler Business School at University of North Carolina. Periodicals Postage Paid at New York, NY and additional mailing offices. POSTMASTER: Send address changes to Journal of Financial and Quantitative Analysis, Cambridge University Press, One Liberty Plaza, 20th Floor, New York, NY 10006, USA. 
JOURNAL OF FINANCIAL AND QUANTITATIVE ANALYSIS

PHONE: (206) 543-4598

FAX: (206) 616-1894

E-MAIL: jfqa@uw.edu

URL: jfqa.org

\section{SUBMISSIONS}

www.editorialmanager.com/jfqa

It is JFQA policy to give prompt attention to all submitted manuscripts. Consistent with this policy, honoraria are paid to referees who provide timely reviews. Submit manuscripts online (www.editorialmanager.com/jfqa). Payment is required at the time of submission. VISA, MasterCard, and American Express are accepted. Please consult the journal Web site for current submission details. Manuscripts are considered for publication on the understanding that they have not been previously published in whole or in part, and are not being simultaneously considered for publication elsewhere.

\section{SUBSCRIPTIONS}

cambridge.org/jfqa

For individuals or institutions interested in a single journal subscription in 2017, please contact Cambridge Journals Customer Services. In the U.S., Canada, or Mexico, subscription fees are payable in U.S. dollars: journals_subscriptions@cambridge.org. Elsewhere in the world, subscription fees are payable in U.K. pounds sterling: journals@cambridge.org

2017 Annual Subscription Fees

Volume 52: February, April, June, August, October, and December

$\begin{array}{lll}\text { Category } & \text { Access Type } & \text { Price } \\ \text { Organizational } & \text { Online \& Print } & \$ 659 / £ 356 \\ \text { Organizational } & \text { Print only } & \$ 659 / £ 356 \\ \text { Organizational } & \text { Online only } & \$ 490 / £ 285 \\ \text { Individual } & \text { Online \& Print } & \$ 116 / £ 63 \\ \text { Individual } & \text { Print only } & \$ 98 / £ 51 \\ \text { Individual } & \text { Online only } & \$ 81 / £ 46 \\ \text { Student } & \text { Print only } & \$ 27 / £ 19\end{array}$

\section{RIGHTS AND PERMISSIONS}

All rights reserved. No part of this publication may be reproduced, in any form or by any means, electronic, photocopying, or otherwise, without permission in writing from Cambridge University Press. General enquiries from the USA, Mexico, and Canada should be addressed to the New York office of Cambridge University Press cambridge.org/us/information/rights/contacts/newyork.htm; general enquiries from elsewhere should be addressed to the Cambridge office cambridge.org/ uk/information/rights/contacts/cambridge.htm; permission enquiries from Australia and New Zealand should be addressed to the Melbourne office cambridge.org/uk/information/rights/contacts/australia.htm; enquiries regarding Spanish language translation rights (only) should be addressed to the Madrid office cambridge.org/uk/information/rights/contacts/madrid.htm. Photocopying information (for users in the USA): Copying for internal or personal use beyond that permitted by Sec. 107 or 108 of the U.S. Copyright Law is authorized for users duly registered with the Copyright Clearance Center (CCC), provided that the appropriate remittance is paid directly to: CCC, 222 Rosewood Drive, Danvers, MA 01923 USA. Specific written permission must be obtained for all other copying; contact the nearest Cambridge University Press office. 


\section{VOTE FOR THE SHARPE BEST PAPER AWARD!}

The William F. Sharpe Award for Scholarship in Financial Research recognizes researchers who, through their articles published in the Journal of Financial and Quantitative Analysis, have most contributed to our understanding of important areas of financial economics. The Sharpe Award nominees are chosen by a vote of JFQA readers and Associate Editors from the papers published in 2016. Winners are selected by the Associate Editors. Access the official ballot at

$$
\text { www.jfqa.org }
$$

Deadline: April 30, 2017 